\title{
Effects of Different Environmental Factors on the Growth and Bioactive Substance Accumulation of Porphyridium purpureum
}

\author{
Xudan Lu, Fangru Nan, Jia Feng, Junping Lv, Qi Liu, Xudong Liu and Shulian Xie *(1) \\ School of Life Science, Shanxi University, Taiyuan 030006, China; luxd9999@163.com (X.L.); \\ nanfr@sxu.edu.cn (F.N.); fengj@sxu.edu.cn (J.F.); lvjunping024@sxu.edu.cn (J.L.); liuqi@sxu.edu.cn (Q.L.); \\ liuxudong@sxu.edu.cn (X.L.) \\ * Correspondence: xiesl@sxu.edu.cn
}

Received: 14 February 2020; Accepted: 25 March 2020; Published: 26 March 2020

\begin{abstract}
Genus Porphyridium is a primitive single-celled red algae widely distributed in seawater, freshwater, and moist soil. It can synthesize bioactive substances such as phycoerythrin, extracellular polysaccharides and polyunsaturated fatty acids during the growth process. In this paper, the culture and bioactive substance yield of Porphyridium purpureum were studied by setting salinity, nitrogen-to-phosphorus ratio, and $\mathrm{pH}$ at different gradient levels. The results showed that the optimal conditions for the growth of P. purpureum were salinity $34 \mathrm{ppt}$, nitrogen-to-phosphorus ratio 169:1, and $\mathrm{pH} 8$; the optimal conditions for obtaining the polysaccharides were salinity $17 \mathrm{ppt}$, nitrogen-to-phosphorus ratio 14:1, and $\mathrm{pH} 8$; the optimal conditions for obtaining phycoerythrin were salinity $17 \mathrm{ppt}$, nitrogen-to-phosphorus ratio 68:1, and $\mathrm{pH} 8$; the optimal conditions for obtaining the lipids were salinity $34 \mathrm{ppt}$, nitrogen-to-phosphorus ratio 1:1, and $\mathrm{pH} 8$. In actual production applications, culture conditions should be set according to different product accumulation purposes in order to achieve the optimal production efficiency.
\end{abstract}

Keywords: Porphyridium purpureum; environmental factors; growth; bioactive substance accumulation

\section{Introduction}

As the world's population and energy demand increase, there is a key issue in finding new renewable energy sources to produce energy. As the most promising source of biomass in biofuel production, microalgae has the most outstanding advantages of high growth rate and high photosynthetic rate in specific environments [1], which is 10 times more capable of fixing $\mathrm{CO}_{2}$ than terrestrial plants, and 30-100 times more efficient energically per hectare than crops [2]. In addition, as a biofuel, microalgae also has the advantages of not occupying cultivated land, not affected by the season, high yield, and no lignin in the cell wall, which is conducive to the production of bioethanol [3]. Microalgae are autotrophic organisms that use light energy and inorganic nutrients (carbon dioxide, nitrogen, phosphorus, etc.) to synthesize valuable biomass compounds such as lipids, proteins, carbohydrates, pigments, etc. They not only provide good raw materials for the production of bio-ethanol and bio-petroleum, but also can be widely used in food, pharmaceutical, and cosmetic industries $[4,5]$.

Porphyridium purpureum (Rhodophyta, Porphyridiophyceae, Porphyridiales, Porphyridiaceae, Porphyridium), which is a relatively primitive single-celled red algae with high salt tolerance, can synthesize valuable bioactive substances such as phycoerythrin, extracellular polysaccharides, and polyunsaturated fatty acids during the growth process. Therefore, it is getting more and more attention [6]. Most of the proteins in the Porphyridium are phycobiliproteins, including phycoerythrin, 
phycocyanin, and allophycocyanin, of which phycoerythrin is the main phycobiliprotein and also the reason why the cells are fuchsia. The phycobiliprotein can be used as a natural pigment in food, cosmetics, dyes, and other industries, and can also be made into fluorescent reagents for clinical medical diagnosis, immunochemistry, bioengineering research, food, and medicine for medical healthcare [7]. In addition, Porphyridium polysaccharides are another high-value compound, wrapped on the cell wall surface in the form of sulfated polysaccharidess. The external part of the polysaccharides is dissolved from the cell surface into the medium during the liquid culture, increasing the viscoelasticity of the medium [8], and the unique rheological property allows them to be used as lubricants and thickeners, etc. [9]. Research by Dvir et al. has shown that Porphyridium polysaccharides have nutritional, medicinal, and cosmetic values [10]. Specially, the polysaccharide extracted from Porphyridium sp. showed antiviral activities and was more effective in inhibiting retrovirus replication and cell transformation by MuSV (murine sarcoma virus) [11-13]. The lipids in Porphyridium are stored mainly in the form of triacylglycerol (TAG), which is transesterified to produce biodiesel and to provide energy for metabolic processes [14]. And some long-chain fatty acids (LC-PUFAs) have high medical value, such as eicosapentaenoic acid (EPA, C20: 5) that reduces the risk of diabetes, brain disease, inflammation, arteriosclerosis, heart disease, and several cancers, and arachidonic acid (ARA, C20: 4), which also has basic functions in the treatment of cardiovascular disease, rheumatoid arthritis, and cancer [15].

Since the 1960s, scholars have researched and made good progress in taxonomy, ecology, nutrition, cultivation, and application of Porphyridium [16]. According to existing studies, microalgae can respond to changing environmental conditions by regulating their metabolites [14], so that changes in environmental conditions can be utilized to achieve a large accumulation of required bioactive substances. The main environmental factors affecting the growth of microalgae are nitrogen and phosphorus concentration, salinity, temperature, light, and $\mathrm{pH}$. Among them, nitrogen and phosphorus are essential nutrients for algae growth, used to synthesize chlorophyll and other photosynthetic pigments, amino acids, nucleic acids, coenzymes, and phospholipids [16], and salinity, as an important factor affecting the growth of microalgae, will also affect the accumulation of microalgae fatty acids and carbohydrates [17]. Therefore, the use of different environmental factors to achieve the large-scale accumulation of required bioactive substances has become the key to Porphyridium research. In recent years, research on the culture conditions of Porphyridium has been relatively rare, and previous literatures only focused on the effects of a certain culture condition on one bioactive product [18-20]. However, the responses to different environmental factors of the most valuable bioactive substances in Porphyridium, including phycoerythrin, polysaccharides and fatty acids, have not been systematically studied.

The purpose of this study was to systematically study the growth and metabolism of P. purpureum at different salinities, nitrogen-to-phosphorus ratios, and $\mathrm{pH}$. The effects of different salinity, nitrogen-to-phosphorus ratio, and $\mathrm{pH}$ on the algal growth characteristics and the unit accumulation of polysaccharides, phycoerythrin, and total lipids were obtained. The novelty of this study is evidenced by clarifying the optimal culture conditions (salinity, nitrogen-to-phosphorus ratio and $\mathrm{pH}$ ) for growth and bioactive substance yields (polysaccharides, phycoerythrin, and total lipids) of P. purpureum. It provides basis for large-scale cultivation, production, and application of P. purpureum in future research.

\section{Materials and Methods}

\subsection{Strains and Culture}

The original species of Porphyridium purpureum was purchased from FACHB (Freshwater Algae Culture Collection at the Institute of Hydrobiology, Wuhan, China), and the algae species number was FACHB-806. Meanwhile, the Kock medium was obtained from the website of FACHB [21]. The main components and volume of the medium are shown in Table 1, and artificial seawater components are shown in Table 2. In addition, the soil extract was configured as follows: 200 g garden soil without 
fertilizer and $1000 \mathrm{~mL} \mathrm{dH_{2 }} \mathrm{O}$ were put in a triangle bottle with a breathable stopper, the mixture was heated in water bath at $100{ }^{\circ} \mathrm{C}$ for $3 \mathrm{~h}$ and then precipitated for $24 \mathrm{~h}$, and this process was performed three times in a row. Then, the mixture was filtered and the supernatant was sterilized in an autoclave and stored in a $4{ }^{\circ} \mathrm{C}$ refrigerator for later use.

Table 1. Kock medium.

\begin{tabular}{ccc}
\hline Components & Volume & Mother Liquor Concentration \\
\hline $\mathrm{KNO}_{3}$ & $10 \mathrm{~mL} / \mathrm{L}$ & $7.5 \mathrm{~g} / 100 \mathrm{ml} \mathrm{dH}_{2} \mathrm{O}$ \\
$\mathrm{KH}_{2} \mathrm{PO}_{4}$ & $1 \mathrm{~mL} / \mathrm{L}$ & $2.5 \mathrm{~g} / 100 \mathrm{ml} \mathrm{dH}_{2} \mathrm{O}$ \\
$\mathrm{MgSO}_{4} .7 \mathrm{H}_{2} \mathrm{O}$ & $10 \mathrm{~mL} / \mathrm{L}$ & $2.0 \mathrm{~g} / 100 \mathrm{ml} \mathrm{dH} \mathrm{H}_{2} \mathrm{O}$ \\
Ferric citrate & $1 \mathrm{~mL} / \mathrm{L}$ & $0.25 \mathrm{~g} / 100 \mathrm{ml} \mathrm{dH}_{2} \mathrm{O}$ \\
Soil extract & $10 \mathrm{~mL} / \mathrm{L}$ & \\
$\mathrm{dH}_{2} \mathrm{O}$ & $484 \mathrm{~mL}$ & \\
Seawater & $484 \mathrm{~mL}$ & \\
\hline
\end{tabular}

Table 2. Artificial seawater components (1 L).

\begin{tabular}{|c|c|}
\hline Components & Dosage \\
\hline $\mathrm{NaCl}$ & $27.0 \mathrm{~g}$ \\
\hline $\mathrm{MgSO}_{4} \cdot 7 \mathrm{H}_{2} \mathrm{O}$ & $6.6 \mathrm{~g}$ \\
\hline $\mathrm{MgCl}_{2} \cdot 6 \mathrm{H}_{2} \mathrm{O}$ & $5.6 \mathrm{~g}$ \\
\hline $\mathrm{CaCl}_{2} \cdot 2 \mathrm{H}_{2} \mathrm{O}$ & $1.5 \mathrm{~g}$ \\
\hline $\mathrm{KNO}_{3}$ & $1.0 \mathrm{~g}$ \\
\hline $\mathrm{KH}_{2} \mathrm{PO}_{4}$ & $0.07 \mathrm{~g}$ \\
\hline $\mathrm{NaHCO}_{3}$ & $0.04 \mathrm{~g}$ \\
\hline 1M Tris- $\mathrm{HCl}$ & $20 \mathrm{~mL}$ \\
\hline Trace element mother liquor & $1 \mathrm{~mL}$ \\
\hline Fe-EDTA (Ethylene Diamine Tetraacetic Acid) & $1 \mathrm{~mL}$ \\
\hline
\end{tabular}

\subsection{Different Growth Condition Treatments}

Based on the principle of controlling a single variable, we set the salinity, nitrogen-to-phosphorus ratio, and $\mathrm{pH}$ at different gradient levels by adjusting the amount of related components in the KOCK medium. The salinity of natural seawater is about 34 ppt. We set four salinity gradients of 0 ppt, 17 ppt, 34 ppt, and 68 ppt by adjusting the amount of seawater components in the medium. With KOCK medium with $\mathrm{KNO}_{3}$ as the nitrogen source, the content was $0.05,0.25,1.0$, and $1.25 \mathrm{~g} / \mathrm{L}$. With $\mathrm{KH}_{2} \mathrm{PO}_{4}$ as the phosphorus source, the content was $0.07,0.025,0.02$, and $0.01 \mathrm{~g} / \mathrm{L}$ in order; the four nitrogen-to-phosphorus ratio gradients were set to $1: 1,14: 1,68: 1$, and 169:1. We set three gradients of $\mathrm{pH} 6, \mathrm{pH} 7$, and $\mathrm{pH} 8$ by adjusting the initial $\mathrm{pH}$ of the medium.

P. purpureum grown to logarithmic phase was inoculated into a $250 \mathrm{~mL}$ erlenmeyer flask containing $200 \mathrm{~mL}$ KOCK medium at an initial concentration of about $2 \times 10^{4}$ cells $/ \mathrm{ml}$. The mixture was then cultured in a light-dark period of $12 \mathrm{~h} / 12 \mathrm{~h}$, the illumination was $60 \mu \mathrm{mol} / \mathrm{m}^{2} / \mathrm{sec}$, and the culture temperature was $(25 \pm 2){ }^{\circ} \mathrm{C}$. The algal solution was shaken about three times a day.

\subsection{Determination of Algae Growth}

Photomicrographs of P. purpureum cells under different growth conditions were taken using an optical microscope, and the effects of different environmental factors on the morphology and growth of $P$. purpureum cells were obtained.

Micro count of P. purpureum cells was conducted by using a cytometry plate every three days, and then the growth curves of P. purpureum under different conditions were drawn. 


\subsection{Determination of Chlorophyll Fluorescence}

After storing $3 \mathrm{~mL}$ algal suspension in the dark for $30 \mathrm{~min}$, two PSII (photosystem II) indexes of chlorophyll fluorescence were determined according to [22] by the portable PAM fluorometer (AquaPen-C AC100, Prague, Czech). The two indexes included the maximum quantum yield of photosystem II photochemistry (Fv/Fm) and the potential activity of photosystem II (Fv/F0).

\subsection{Determination of Polysaccharides Content}

First, $20 \mathrm{~mL}$ of algal suspension was taken and centrifuged at $6000 \mathrm{rpm}$ for 10 minutes, the supernatant was discarded, the algae was freeze-dried for 24 hto obtain the algal powder, and the

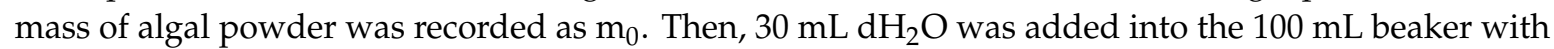
the algal powder, the mixture was concentrated in a water bath at $80^{\circ} \mathrm{C}$ to about one-third of the original volume, and the final volume was recorded as V. Next, the mixture was centrifuged at $6000 \mathrm{rpm}$ for $5 \mathrm{~min}$, and the supernatant was taken as the crude polysaccharides solution. Finally, polysaccharides concentration was determined according to the phenol-sulfuric acid method [23], that was, $5 \mathrm{~mL}$ concentrated sulfuric acid and $1 \mathrm{~mL} 6 \%$ phenol were added to a test tube with $1 \mathrm{~mL}$ polysaccharides solution, the mixture was heated in a water bath at $100^{\circ} \mathrm{C}$ for $15 \mathrm{~min}$, and the absorbance value was measured at $490 \mathrm{~nm}$ after cooling. The polysaccharides concentration, $\mathrm{C}_{0}$, was calculated based on a standard curve, which drawn based on a $40 \mu \mathrm{g} / \mathrm{ml}$ glucose standard solution [24]. The polysaccharides content (PC) was calculated according to the following formula:

$$
\mathrm{PC}(\%)=\mathrm{C}_{0} \mathrm{~V} / \mathrm{m}_{0} \times 100 \%
$$

\subsection{Determination of Phycoerythrin Content}

First, $20 \mathrm{~mL}$ of algal suspension was lyophilized into algal powder after a series of treatments, and the mass of the algal powder was recorded as $\mathrm{m}_{0}$. Subsequently, the algal powder was suspended with $5 \mathrm{~mL}$ phosphate buffer solution $(10 \mathrm{mmol} / \mathrm{L}, \mathrm{pH} 7.0)$. Next, the suspension was frozen in $-80^{\circ} \mathrm{C}$ refrigerator for 1 hour and thawed in water bath at $37^{\circ} \mathrm{C}$, this process was repeated three times, and then the algal cell was broken by an ultrasonic crusher (SCIENTZ-IID, Scientz, Ningbo, China) at $20 \%$ (at the rated power) for $5 \mathrm{~min}$. Then, the suspension was centrifuged at $6000 \mathrm{rpm}, 4{ }^{\circ} \mathrm{C}$ for $5 \mathrm{~min}$, and the supernatant was saved. Finally, the absorbance value was measured at $595 \mathrm{~nm}$ according to the Bradford method [25], and then the phycoerythrin concentration, $\mathrm{C}_{0}$, was calculated according to the standard curve, which was drawn based on a $100 \mu \mathrm{g} / \mathrm{ml}$ BSA (bovine serum albumin) standard solution [26]. The phycoerythrin content (RC) was calculated according to the following formula:

$$
\mathrm{RC}(\%)=5 \mathrm{C}_{0} / \mathrm{m}_{0} \times 100 \%
$$

\subsection{Determination of Total Lipids Content}

Total lipids content was determined gravimetrically according to the modified Bligh and Dyer methods [27]. First, the algal cultivation broth in the stationary phase was lyophilized into algae powder after a series of treatments, and the mass of algae powder was recorded as $\mathrm{m}_{0}$. Subsequently, $2 \mathrm{~mL}$ chloroform and $4 \mathrm{~mL}$ methanol were added into the glass bottle with the algal powder, and the mixture was placed in an ultrasonic crusher to break up cells. Next, the mixture was centrifuged at $5000 \mathrm{rpm}$ for 5 minutes, the supernatant was collected in a new glass bottle, the mass of the empty glass bottle was recorded as $\mathrm{m}_{1}$. The above steps were repeated at least three times. Then, $1 \% \mathrm{NaCl}$ solution was added into the collected supernatant until the layer was separated, and the lower layer was saved. Finally, the lipids solution in the glass bottle was dried under nitrogen flow, and the mass of the glass bottle with the lipids was recorded as $\mathrm{m}_{2}$ [28]. The total lipids content (LC) was calculated according to the following formula:

$$
\mathrm{LC}(\%)=\left(\mathrm{m}_{2}-\mathrm{m}_{1}\right) / \mathrm{m}_{0} \times 100 \%
$$




\subsection{Statistical Analysis}

The experiment was replicated three times. All data were expressed as mean \pm standard error. One-way ANOVA was used to test the significance of different environmental factors on the growth and organic matter accumulation of P. purpureum $(p \leq 0.05)$. All statistical analyses were carried out using the SPSS19.0 statistical software (IBM Inc. Chicago, IL, USA).

\section{Results}

\subsection{Algal Growth}

\subsubsection{Microscopic Observation}

As shown in Figure 1a, when the salinity of medium was 0 ppt (fresh water conditions), the growth status of P. purpureum was the worst, the cell vitality was the weakest, and the pigment bodies were star-shaped, but the color was lighter. The shape of pigment bodies became irregular as salinity was raised. The diameter of P. purpureum cells was the largest at salinity $68 \mathrm{ppt}$. As shown in Figure $1 \mathrm{~b}$, the size of a single P. purpureum cell increased as the nitrogen-to-phosphorus ratio was raised. The pigment bodies showed a star shape at nitrogen-to-phosphorus ratio 68: 1 but showed an irregular shape at other nitrogen-to-phosphorus ratios. As shown in Figure 1c, the cell vitality was relatively weak and the pigment bodies shrank at $\mathrm{pH} 6$ and $\mathrm{pH}$ 7, but P. purpureum cells were more vigorous at $\mathrm{pH} 8$. The cell size showed an increasing trend with the increase of $\mathrm{pH}$.

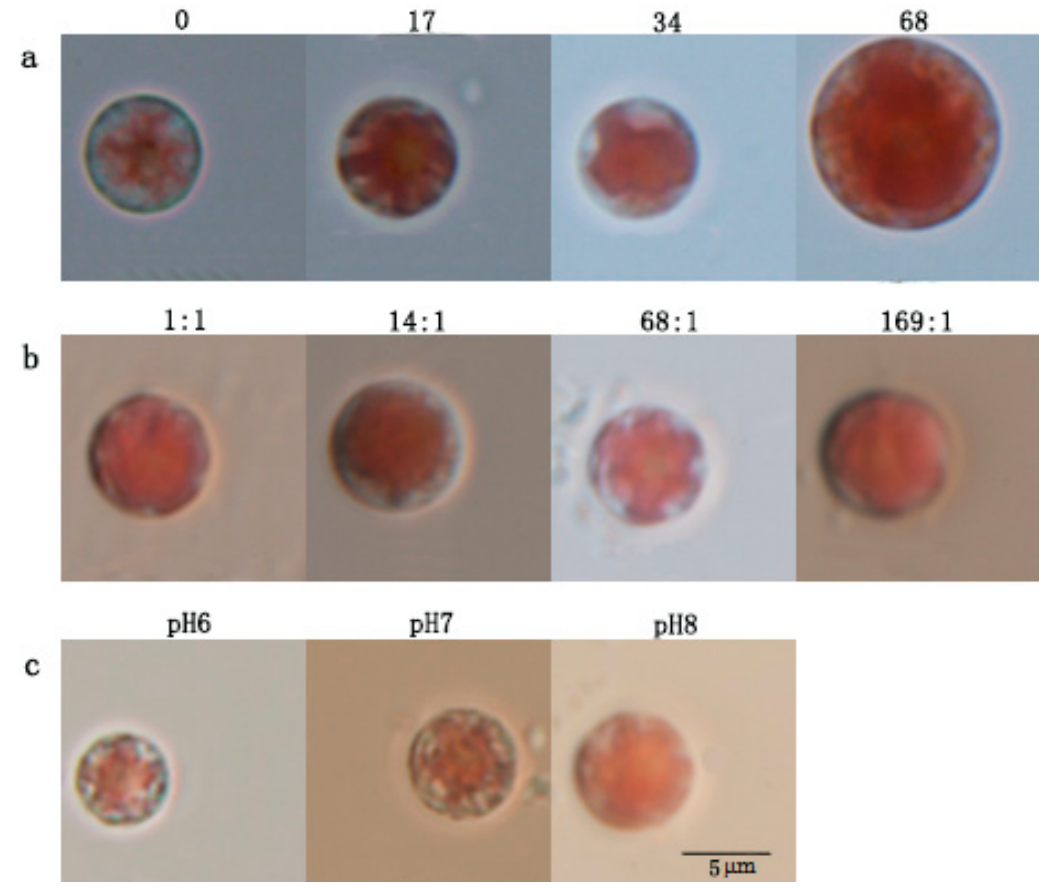

Figure 1. Cell morphology of $P$. purpureum under different conditions; the photos were taken under a $100 \times$ optical microscope. (a). Cell morphology of P. purpureum at different salinities. (b). Cell morphology of P. purpureum at different nitrogen-to-phosphorus ratios. (c). Cell morphology of P. purpureum at different $\mathrm{pH}$ conditions.

\subsubsection{Growth Curve}

As shown in Figure 2, P. purpureum entered the stationary phase on the 17th day under different salinities and $\mathrm{pH}$ conditions and on the 20th day under different nitrogen-to-phosphorus ratios, but the effects on the growth rate and cell density of $P$. purpureum were different under different environmental factors. As shown in Figure 2a, the cell density in the stationary phase at different salinities was $34 \mathrm{ppt}>$ 
$17 \mathrm{ppt}>68 \mathrm{ppt}>0 \mathrm{ppt}$ in order. P. purpureum showed the same growth trend and similar cell density in the logarithmic growth phase at salinity $17 \mathrm{ppt}$ and $34 \mathrm{ppt}$. The growth was milder and the growth rate was lower at salinity $0 \mathrm{ppt}$ than in the other salinity experiment group, and P. purpureum could still grow normally and reach a high cell density of 1,571,500 cells/ml at salinity $68 \mathrm{ppt}$ (high-salinity conditions). As shown in Figure $2 b$, the cell density in the stationary phase at different nitrogen-to-phosphorus ratios was 169:1 > 68:1 14:1 > 1:1 in order, and it showed an increasing trend with the increase of the nitrogen-to-phosphorus ratio. As shown in Figure 2c, the cell density in the stationary phase at different $\mathrm{pH}$ was $\mathrm{pH} 8>\mathrm{pH} 7>\mathrm{pH} 6$ in order. P. purpureum grew faster in the prologarithmic phase at $\mathrm{pH} 7$, but grew faster and started to exhibit the highest cell density in the postlogarithmic phase at $\mathrm{pH} 8$.
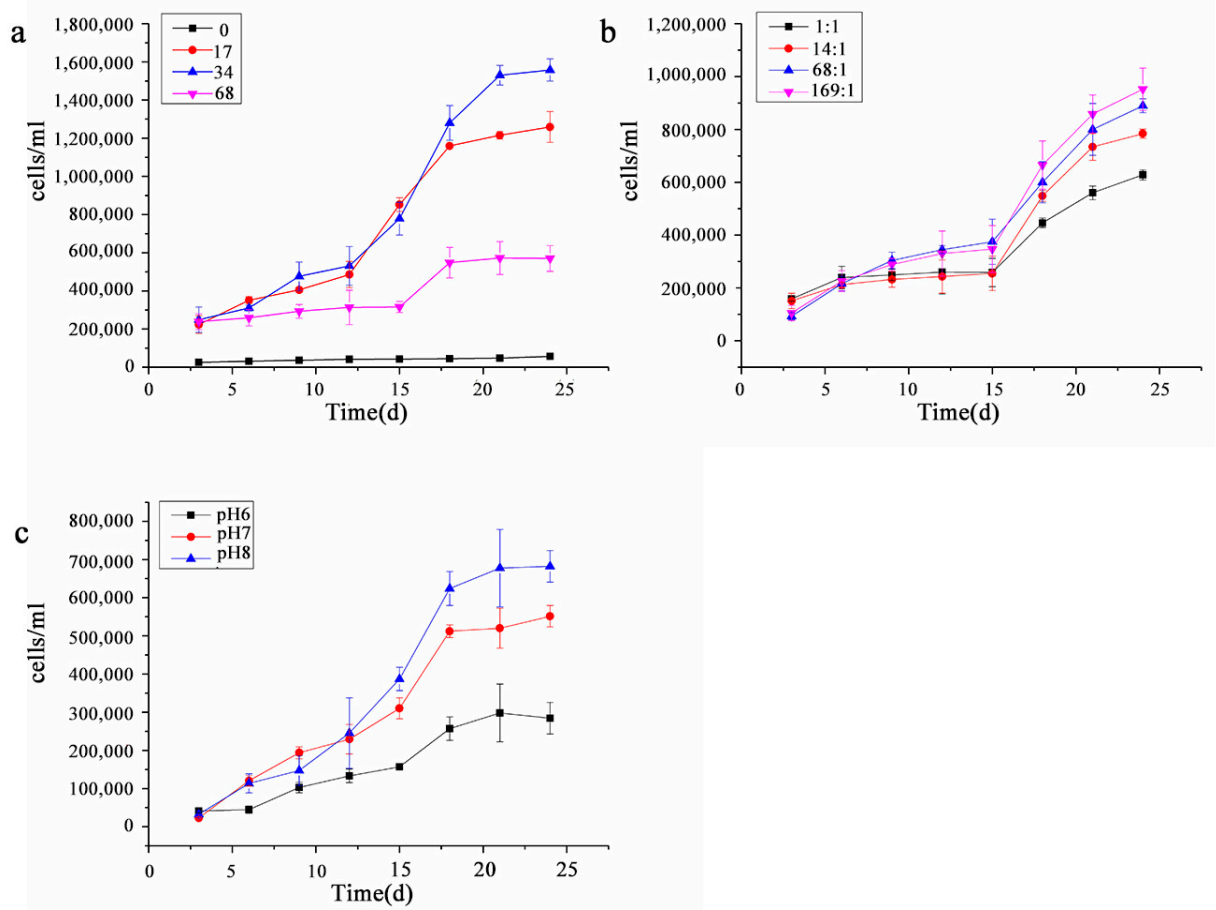

Figure 2. Growth curves of $P$. purpureum under different environmental factors. Data were expressed as mean \pm standard error. (a). The growth curves of P. purpureum at different salinities. (b). The growth curves of P. purpureum at different nitrogen to phosphorus ratios. (c). The growth curves of P. purpureum at different $\mathrm{pH}$ conditions.

\subsection{Analysis of Chlorophyll Fluorescence}

As shown in Figure 3, the chlorophyll fluorescence parameters, Fv/ Fo and Fv/ Fm, showed variable trends under different conditions. As shown in Figure 3a, the chlorophyll fluorescence parameters were the largest at salinity $17 \mathrm{ppt}$ from 0 to 6 days, followed by that at salinity $34 \mathrm{ppt}$ and $68 \mathrm{ppt}$, with the smallest at salinity $0 \mathrm{ppt}$ (fresh water conditions). The chlorophyll fluorescence parameters showed a steady trend from 7 to 18 days. However, they showed a slow downward trend after 19 days, the chlorophyll fluorescence parameters were the largest at salinity $68 \mathrm{ppt}$, followed by those at salinity $34 \mathrm{ppt}$ and $17 \mathrm{ppt}$, with the smallest at salinity $0 \mathrm{ppt}$, and there was no significant difference in chlorophyll fluorescence parameters under different salinities. As shown in Figure 3b, the chlorophyll fluorescence parameters at different nitrogen-to-phosphorus ratios showed an upward trend from 0 to 10 days. However, they began to show a slow downward trend after 11 days, and they were always the smallest at the nitrogen-to-phosphorus ratio 1:1. As shown in Figure 3c, the chlorophyll fluorescence parameters gradually stabilized after 21 days, and they were always the highest at $\mathrm{pH} 8$, followed by those at $\mathrm{pH} 7$, and the smallest at $\mathrm{pH} 6$. 

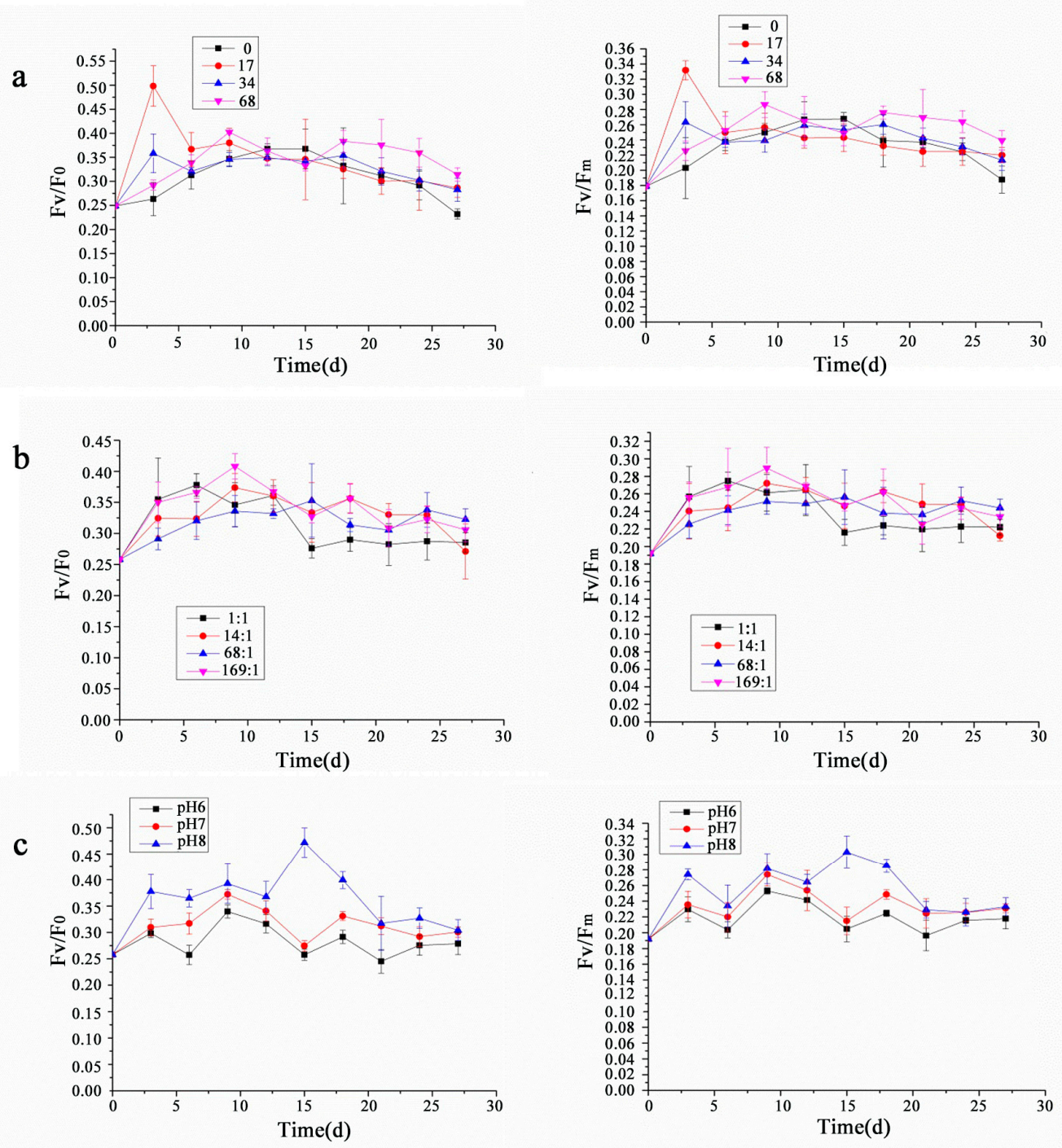

Figure 3. The chlorophyll fluorescence of P. purpureum under different environmental factors. Data were expressed as mean \pm standard error. (a). The chlorophyll fluorescence of $P$. purpureum at different salinities. (b). The chlorophyll fluorescence of P. purpureum at different nitrogen-to-phosphorus ratios. (c). The chlorophyll fluorescence of P. purpureum at different $\mathrm{pH}$ conditions.

\subsection{Contents of Polysaccharides}

As shown in Figure 4, the content of polysaccharides per unit algal powder under different conditions gradually increased with time, and it began to accumulate in large quantities especially in the postlogarithmic phase. Therefore, the total amount of polysaccharides had a significant positive correlation with the cell growth.

As shown in Figure 4a, the accumulation of polysaccharides at different salinities reached the maximum on the 25th day, and polysaccharides contents at salinity 0 and 68 were relatively lower, respectively $5.52 \%$ and $4.46 \%, 7.42 \%$ at salinity $34 \mathrm{ppt}$, the highest at salinity $17 \mathrm{ppt}$, which was to $9.05 \%$, and there were significant differences between polysaccharides contents under different salinities. As shown in Figure $4 b$, the polysaccharides content at different nitrogen-to-phosphorus ratios (except 1:1) showed a slight downward trend on the 25th day. The polysaccharides content was the largest at nitrogen-to-phosphorus ratio 14:1 compared with other groups from the day of inoculation to the stationary phase, especially on the 20th day, which was $10.50 \%$, and there was significant difference in polysaccharides content between nitrogen-to-phosphorus ratio 1:1 and other groups. As shown in 
Figure $4 \mathrm{c}$, from the day of inoculation to the stationary growth phase, the polysaccharides content was always the highest at $\mathrm{pH} 8$, followed by that at $\mathrm{pH} 7$, with the lowest at $\mathrm{pH} 6$, and the maximum accumulation at different $\mathrm{pH}$ was reached on the 25 th day, $10.44 \%, 7.81 \%$, and $7.66 \%$, respectively, and there was a significant difference between the polysaccharides content at $\mathrm{pH} 8$ and other groups.
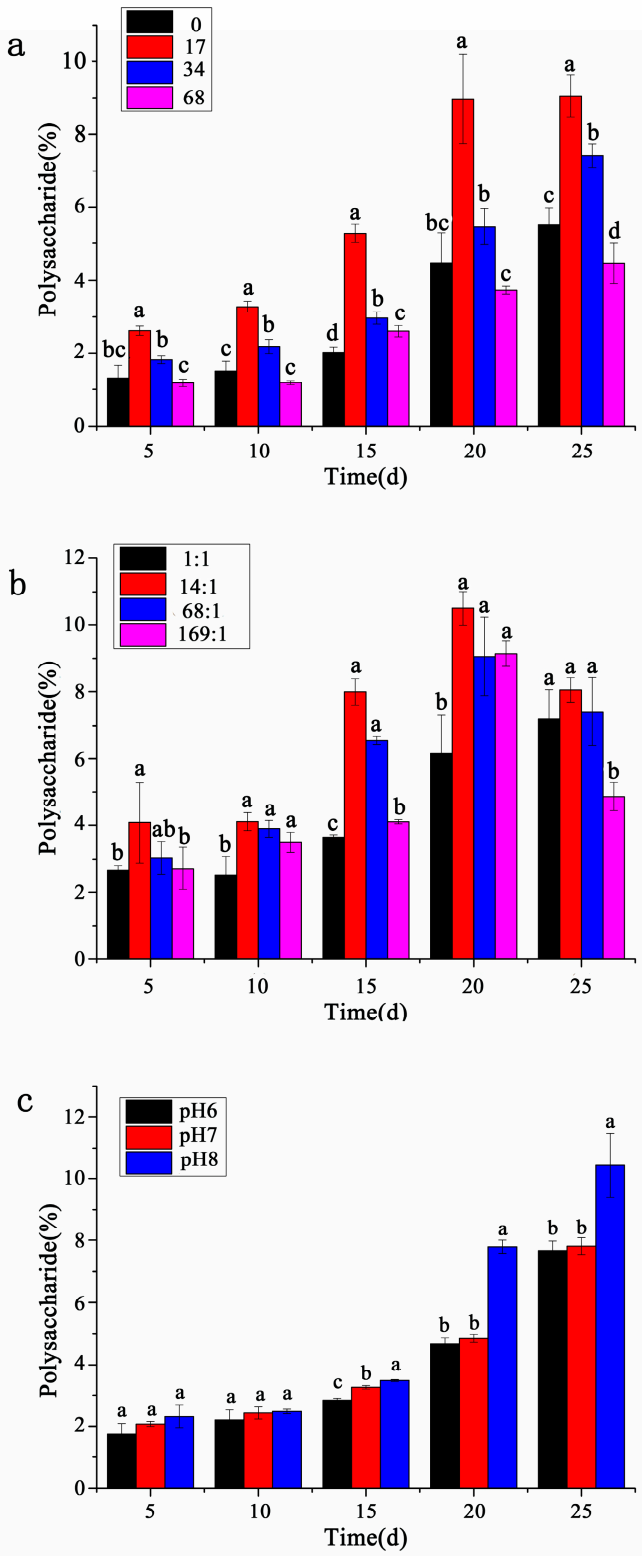

Figure 4. The content of polysaccharides of P. purpureum under different environmental factors. Data were expressed as mean \pm standard error. (a). P. purpureum polysaccharides content at different salinity. (b). P. purpureum polysaccharides content at different nitrogen-to-phosphorus ratios. (c). P. purpureum polysaccharides content at different $\mathrm{pH}$ conditions.

\subsection{Contents of Phycoerythrin}

As shown in Figure 5, the content of phycoerythrin per unit algal powder under different conditions gradually increased with time, and it began to accumulate in large quantities especially in the postlogarithmic phase. Therefore, the total amount of phycoerythrin had a significant positive correlation with the cell growth. However, there was a difference that the phycoerythrin content at different salinities showed a slight downward trend on the 25th day (Figure 5a). In addition, the accumulation of phycoerythrin at different salinities reached the maximum on the 20th day, and the 
phycoerythrin contents at salinity $0 \mathrm{ppt}, 34 \mathrm{ppt}$, and $68 \mathrm{ppt}$ were relatively low, respectively $5.52 \%$, $3.75 \%$, and $2.14 \%$, highest at salinity $17 \mathrm{ppt}$, with a content of $8.81 \%$, and there were significant differences between the phycoerythrin contents at different salinities.
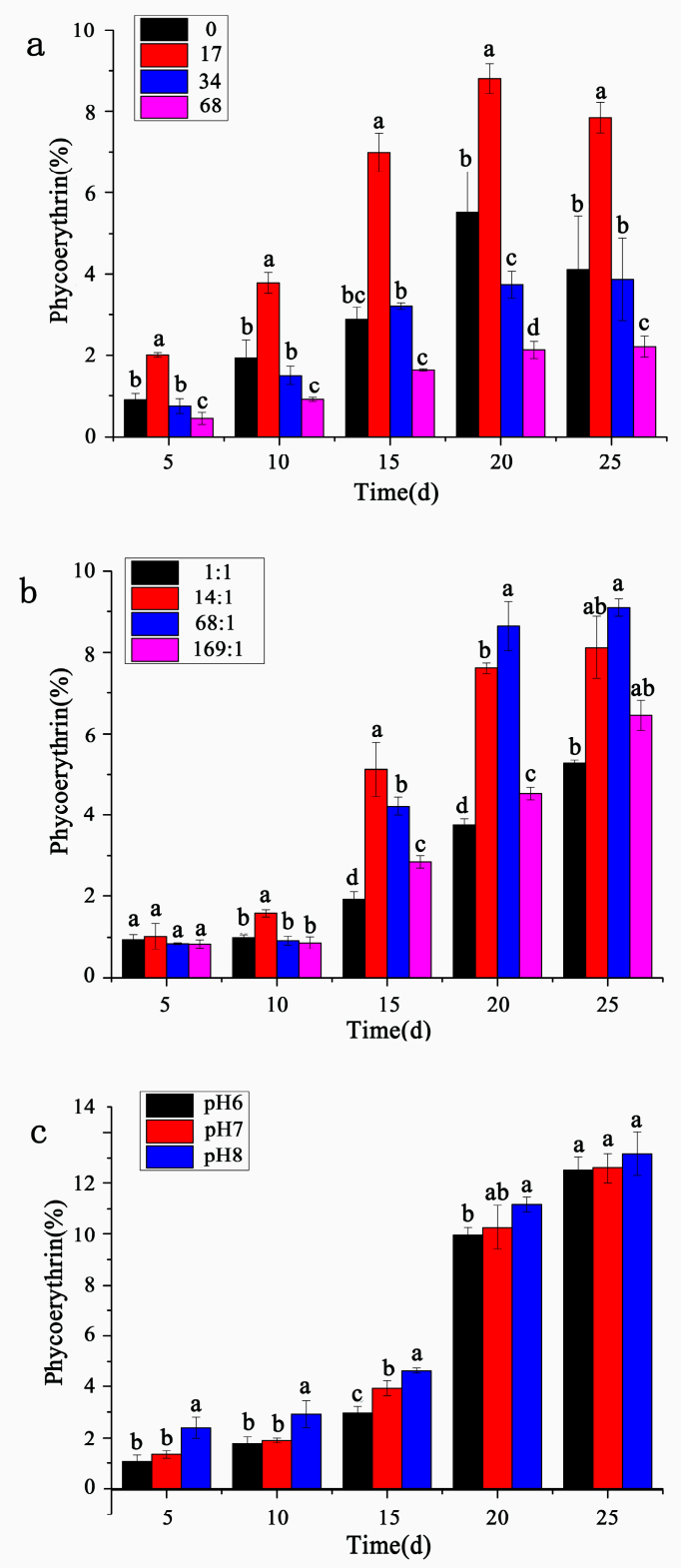

Figure 5. The content of phycoerythrin of P. purpureum under different environmental factors. Data were expressed as mean \pm standard error. (a). The content of phycoerythrin of $P$. purpureum at different salinities. (b). The content of phycoerythrin of P. purpureum at different nitrogen-to-phosphorus ratios. (c). The content of phycoerythrin of P. purpureum at different $\mathrm{pH}$ conditions.

As shown in Figure 5b, the phycoerythrin content was always highest at nitrogen-to-phosphorus ratio 14:1 from 0 to 15 days (before reaching the stationary phase), but was the highest at nitrogen-to-phosphorus ratio 68:1 after entering the stationary growth phase. On the 25th day, the content at nitrogen-to-phosphorus ratio $68: 1$ was $9.09 \%$, there was only a significant difference between the phycoerythrin content at nitrogen-to-phosphorus ratio 68:1 and nitrogen-to-phosphorus ratio $1: 1$. On the 20th day, the content at nitrogen-to-phosphorus ratio $68: 1$ was $8.64 \%$, however, there were significant differences between the phycoerythrin content at different nitrogen-to-phosphorus ratios. As shown in Figure 5c, from 0 to 25 days, the phycoerythrin content was always the highest at 
$\mathrm{pH} 8$, followed by that at $\mathrm{pH} 7$, with the lowest at $\mathrm{pH} 6$, and the accumulation of phycoerythrin at different $\mathrm{pH}$ reached the maximum on the 25 th day, $13.16 \%, 12.58 \%$, and $12.50 \%$, respectively, and there was no significant difference between the phycoerythrin content at different $\mathrm{pH}$.

\subsection{Contents of Total Lipids}

As shown in Figure 6a, on the 20th day, the total lipid content was highest at salinity $34 \mathrm{ppt}$, with a content of $10.65 \%$, the contents at $17 \mathrm{ppt}, 68 \mathrm{ppt}$, and $0 \mathrm{ppt}$ were relatively low, respectively $10.48 \%$, $9.53 \%$, and $8.91 \%$. There was no significant difference in the total lipid content between salinity $0 \mathrm{ppt}$ and $68 \mathrm{ppt}$, and there was no significant difference in the total lipid content between salinity $17 \mathrm{ppt}$ and 34 ppt.
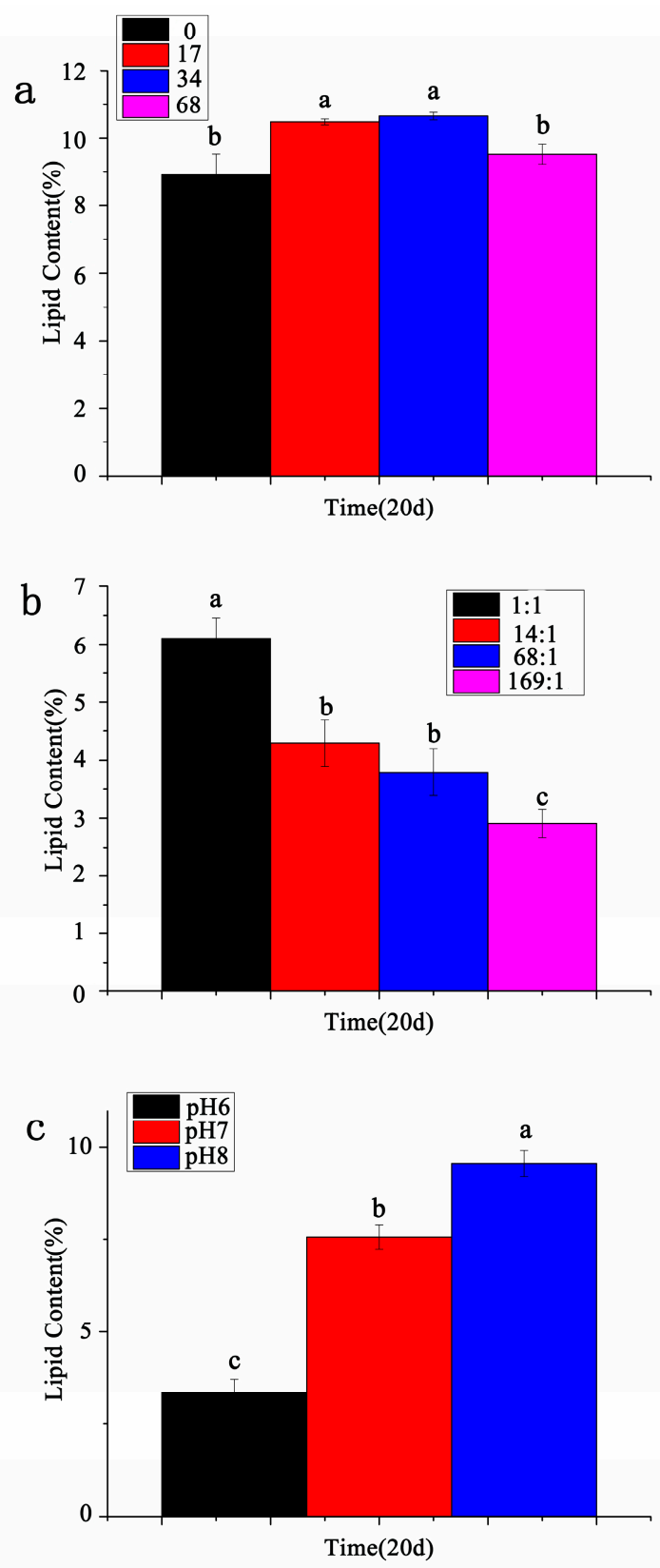

Figure 6. The content of total lipids of P. purpureum under different environmental factors. Data were expressed as mean \pm standard error. (a). P. purpureum total lipid content under different salinity; (b). P. purpureum total lipid content under different N:P ratios; (c). P. purpureum total lipid content under different $\mathrm{pH}$ conditions. 
As shown in Figure 6b, on the 20th day, the total lipid content of P. purpureum at different nitrogen-to-phosphorus ratios was 1:1>14:1 > 68:1 > 169:1 in order, which were 6.10\%, 4.29\%, 3.79\%, and $2.91 \%$, respectively. There was only no significant difference in total lipid content between nitrogen-to-phosphorus ratio 14:1 and 68:1, but there were significant differences among the other nitrogen and phosphorus ratio experimental groups. As shown in Figure $6 \mathrm{c}$, on the 20th day, the total lipid content of P. purpureum at different $\mathrm{pH}$ was $\mathrm{pH} 8>\mathrm{pH} 7>\mathrm{pH} 6$ in order, which were $9.56 \%, 7.56 \%$, and $3.35 \%$, respectively, and there were significant differences in the total lipid content at different $\mathrm{pH}$.

\section{Discussion}

The growth and metabolism of P. purpureum under different environmental factors were studied in this paper. The experimental results showed that P. purpureum grew slowly under conditions of excessively high or low salinity, especially in fresh water, where the cell viability was weak and the growth rate was low. Previous studies had shown that the competitive strength of Porphyridium was relatively weak when the salt concentration was less than $3.5 \%$, and there was no inhibitory effect on its growth with the salt concentration up to $4.6 \%$ [29]. In addition, the growth of Porphyridium in seawater was relatively faster compared with freshwater in the early culture period, which was similar to our results [30]. It was reported that Porphyridium in seawater began to decline and Porphyridium in freshwater began to grow in the later period, and the logarithmic phase and survival time of Porphyridium in freshwater were prolonged [30]. Therefore, we can achieve the production purpose of obtaining a high concentration of algae through phased cultivation. Seawater culture can be used to rapidly grow and accumulate $P$. purpureum cells in initial cultivation, and freshwater culture can be used to prolong the survival time of the cells and make biomass continue to increase and accumulate in the later cultivation.

The content of polysaccharides and phycoerythrin of P. purpureum cells was highest at salinity $17 \mathrm{ppt}$ and it showed a downward trend as the salinity was raised, which indicated that the low-salt environment was beneficial to the accumulation of soluble polysaccharides and phycoerythrin. It is possible that $\mathrm{Na}^{+}$and $\mathrm{Mg}^{2+}$ compete for the ribosome in a high-salt environment to inhibit protein synthesis [31]. In addition, the content of total lipid of P. purpureum was the highest at salinity $34 \mathrm{ppt}$, an indication that salt stress was beneficial to the accumulation of lipid to a certain extent, which was consistent with the report of Porphyridium [32]. According to the report, salt stress could enhance the accumulation of lipid in various microalgae, which may be due to the response of microalgae to salt stress through the accumulation of compatible solutes [33]. Therefore, low-salt environment can be exploited to accumulate polysaccharides, and high-salt stress can be used to achieve large-scale synthesis of lipid, which provides good raw materials and methods for the mass production of bioethanol and biodiesel.

The Redfeld ratio (C:N:P = 106:16:1 atomic ratio) [34] has long been used as the optimal nitrogen-to-phosphorus ratio for the growth of phytoplankton, but different phytoplankton have different needs for nutrients in their growth process. In this paper, the biomass accumulation of $P$. purpureum in the stationary phase showed an upward trend with the increase of the nitrogen-to-phosphorus ratio. The cell concentration in the stationary growth phase was highest at nitrogen-to-phosphorus ratio 169:1, which was much higher than the optimal nitrogen-to-phosphorus ratio 16:1 for algae, but lowest at nitrogen-to-phosphorus ratio 1:1, indicating that the growth rate and cell concentration of P. purpureum increased when the nitrogen source was excessive and decreased when the nitrogen source was limited, which was consistent with previous research [35]. Studies have shown that the microalgae tended to decrease the rate of growth and photosynthesis, and also tended to degrade nitrogen-containing macromolecules such as proteins to store a large amount of carbon and energy-rich compounds in order to resist the adverse environment, so there was a large accumulation of carbohydrates and lipids under nitrogen starvation $[3,36]$. In this paper, the content of total lipid of P. purpureum was highest at nitrogen-to-phosphorus ratio 1:1, the content of polysaccharides was highest at the nitrogen-to-phosphorus ratio 14:1, and the content of phycoerythrin was highest at 
nitrogen-to-phosphorus ratio 68:1 (high-nitrogen environment). The low-nitrogen environment was not conducive to protein accumulation but was conducive to the accumulation of polysaccharides and lipid, which was consistent with existing reports. The content of lipid and carbohydrate is significantly increased in various microalgae species under nitrogen starvation, eventually the biofuel production potential of microalgae is improved, but nutritional starvation resulted in reduced biomass and reduced biofuel production. To overcome this problem, researchers have proposed a two-phase culture strategy in which microalgae first grow under sufficient nutrition to produce sufficient biomass, and then grow under nitrogen limitation to produce abundant carbohydrate and lipid [37].

The effect of $\mathrm{pH}$ on the growth of Porphyridium was mainly manifested in changing the permeability of the cell membrane and the activity of intracellular enzymes, eventually the entry and exit of nutrients and cell metabolism were affected [16]. Previous studies have shown that Porphyridium can grow normally at $\mathrm{pH}$ 5.0 8.3 [38], and its optimum $\mathrm{pH}$ growth range was $\mathrm{pH} 7.5 \sim 8.0$ [16], which was similar to our result that the optimal condition for P. purpureum growth was at $\mathrm{pH}$ 8.0. And the result that the content of phycoerythrin was highest at $\mathrm{pH} 8$ was consistent with our study, but the result that $\mathrm{pH}$ 5 was the optimal environment for obtaining extracellular polysaccharides content $[39,40]$ was not consistent with our result. We analyze the possible reasons for this. Our experiments were conducted in lab using the species P. porphyridium, whereas the results of optimal $\mathrm{pH} 5$ in previous studies were obtained based on outdoor mass cultures or using a different species P. cruentum [39,40]. The optimal $\mathrm{pH}$ for producing extracellular polysaccharides was related with the experimental environments and algal species. The total lipids content was the lowest at $\mathrm{pH} 6$. The possible reason is that the acidic environment inhibits related enzyme activities during the synthesis of long-chain fatty acids, such as dehydrogenase, oxygenase, and chain elongase, thereby blocking the conversion to long-chain fatty acids [41] and ultimately leading to a relatively low total lipid content.

Comprehensively speaking, culture condition is a very important factor in the cultivation of P. purpureum [30]. Therefore, it is of great significance to monitor the effect of different environmental factors (salinity, nitrogen-to-phosphorus ratio, and $\mathrm{pH}$ ) on the growth and accumulation of bioactive substances of P. purpureum. First of all, the cultivation cell number and chlorophyll fluorescence under different conditions were monitored during cultivation, thus the optimal growth conditions and the algal species harvest time can be obtained, which provides data support for the cultivation optimization of Porphyridium in actual production. At the same time, the application value of bioactive substances synthesized by Porphyridium during the growth process in medicine, food, or other industries makes their maximum amount production a key. Therefore, the optimal combination of conditions for producing bioactive substance were obtained by monitoring their contents under different conditions during cultivation, which provides theoretical support for improving and optimizing the production of bioactive substances, and also provides good materials for industrial production.

\section{Conclusions}

The effects of salinity, nitrogen-to-phosphorus ratio, and $\mathrm{pH}$ on the algal growth, polysaccharides, phycoerythrin, and total lipid content of P. purpureum were studied. The results showed that the optimal conditions for the growth of P. purpureum were salinity 34 ppt, nitrogen-to-phosphorus ratio 169:1, and $\mathrm{pH}$ 8. The optimal conditions for obtaining polysaccharides of P. purpureum were salinity $17 \mathrm{ppt}$, nitrogen-to-phosphorus ratio $14: 1$, and $\mathrm{pH}$ 8. The optimal conditions for obtaining phycoerythrin were salinity $17 \mathrm{ppt}$, nitrogen-to-phosphorus ratio 68:1, and $\mathrm{pH}$ 8. The optimal conditions for obtaining lipid were salinity $34 \mathrm{ppt}$, nitrogen-to-phosphorus ratio 1:1, and $\mathrm{pH} 8$. In addition, the low-salt and low-nitrogen environment were conducive to the accumulation of carbon-rich compounds in the cell, such as polysaccharides and triacylglycerol. Therefore, it is possible to achieve the purpose of accumulating a large amount of bioactive substances by regulating the growth conditions of P. purpureum. 
Author Contributions: Conceptualization, S.X.; Data curation, X.L. and F.N.; Formal analysis, X.L., J.F., J.L., Q.L. and X.L.; Funding acquisition, S.X. and F.N.; Writing—original draft, X.L. and F.N.; Writing-review \& editing, S.X. All authors have read and agreed to the published version of the manuscript.

Funding: This research project was funded by the Applied Basic Research Project of Shanxi, China (No. 201801D221245), Scientific and Technological Innovation Programs of Higher Education Institutions in Shanxi (No. 2019L0078), and the "1331" Project of Shanxi, China.

Acknowledgments: We are grateful to MDPI and Liwen Proofediting for the editorial assistance with the English.

Conflicts of Interest: The authors declare no conflict of interest.

\section{References}

1. Klein-Marcuschamer, D.; Chisti, Y.; Benemann, J.R.; Lewis, D. A matter of detail: Assessing the true potential of microalgal biofuels. Biotechnol. Bioeng. 2013, 110, 2317-2322.

2. Sun, Y.; Cheng, J. Hydrolysis of lignocellulosic materials for ethanol production: A review. Cheminform 2003, 83, 1-11. [CrossRef]

3. Kim, K.H.; Choi, I.S.; Kim, H.M.; Wi, S.G. Bioethanol production from the nutrient stress-induced microalga Chlorella vulgaris by enzymatic hydrolysis and immobilized yeast fermentation. Bioresour. Technol. 2014, 153, 47-54. [CrossRef] [PubMed]

4. Singh, A.; Nigam, P.S.; Murphy, J.D. Mechanism and challenges in commercialisation of algal biofuels. Bioresour. Technol. 2011, 102, 26-34. [CrossRef] [PubMed]

5. Brennan, L.; Owende, P. Biofuels from microalgae: Towards meeting advanced fuel standards. In Advanced Biofuels and Bioproducts; Lee, J., Ed.; Springer: New York, NY, USA, 2013; pp. 553-599.

6. Gaignard, C.; Gargouch, N.; Dubessay, P.; Delattre, C.; Pierre, G. New horizons in culture and valorization of red microalgae. Biotechnol. Adv. 2019, 37, 193-222. [CrossRef] [PubMed]

7. Thoisen, C.; Hansen, B.W.; Nielsen, S.L. A simple and fast method for extraction and quantification of cryptophyte phycoerythrin. MethodsX 2017, 4, 209-213. [CrossRef]

8. Arad, S.; Levy-Ontman, O. Red microalgal cell-wall polysaccharidess: Biotechnological aspects. Curr. Opin. Biotechnol. 2010, 21, 358-364. [CrossRef]

9. Ramus, J.; Kenney, B.E. Shear degradation as a probe of microalgal exopolymer structure and rheological properties. Biotechnol. Bioeng. 1989, 34, 1203-1208. [CrossRef]

10. Dvir, I.; Chayoth, R.; Sod-Moriah, U.; Shany, S.; Nyska, A. Soluble polysaccharides and biomass of red microalga Porphyridium sp. alter intestinal morphology and reduce serum cholesterol in rats. Br. J. Nutr. 2000, 84, 469-476. [CrossRef]

11. González, M.E.; Alarcón, B.; Carrasco, L. Polysaccharidess as antiviral agents: Antiviral activity of carrageenan. Antimicrob. Agents Chemother. 1987, 31, 1388-1393. [CrossRef]

12. Sugawara, I.; Itoh, W.; Kimura, S.; Mori, S.; Shimada, K. Further characterization of sulfated homopolysaccharidess as anti-HIV agents. Experientia 1989, 45, 996-998. [CrossRef]

13. Talyshinsky, M.M.; Souprun, Y.Y.; Huleihel, M.M. Anti-viral activity of red microalgal polysaccharides against retroviruses. Cancer Cell Int. 2002, 2, 8. [CrossRef]

14. Paliwal, C.; Mitra, M.; Bhayani, K.; Bharadwaj, S.V.; Ghosh, T. Abiotic stresses as tools for metabolites in microalgae. Bioresour. Technol. 2017, 244, 1216-1226. [CrossRef]

15. Hu, H.; Wang, H.F.; Ma, L.L.; Shen, X.F.; Zeng, J.X. Effects of nitrogen and phosphorous stress on the formation of high value LC-PUFAs in Porphyridium cruentum. Appl. Microbiol. Biotechnol. 2018, 102, 5763-5773. [CrossRef] [PubMed]

16. Jia, S.Y. Effects of Different Salinities and Nitrogen and Phosphorus Concentrations on the Growth and Metabolism of Porphyridium. Master's Thesis, Dalian University of Technology, Dalian, China, 2006.

17. Xia, L.; Rong, J.F.; Yang, H.J.; He, Q.N.; Zhang, D.L. $\mathrm{NaCl}$ as an effective inducer for lipid accumulation in freshwater microalgae Desmodesmus abundans. Bioresour. Technol. 2014, 161, 402-409. [CrossRef] [PubMed]

18. Yuan-Kun, L.; Hai-Meng, T.; Ching-Seng, L. Effect of salinity of medium on cellular fatty acid composition of marine algae Porphyridium cruentum (Rhodophyceae). J. Appl. Phycol. 1989, 1, 19-23.

19. Gilles, R.; Pequeux, A. Effect of salinity on the free amino acids pool of the red alga Porphyridium purpureum (= P. cruentum). Comp. Biochem. Physiol. Part A Physiol. 1977, 57, 183-185. [CrossRef] 
20. Hasanah, H.; Setyaningsih, I.; Uju, U. Harvesting and separation technique of Porphyridium cruentum polysaccharide using ultrafiltration membrane. Jurnal Pengolahan Hasil Perikanan Indonesia 2016, 19, 110-120. [CrossRef]

21. Freshwater Algae Culture Collection at the Institute of Hydrobiology Home Page. Available online: http://algae.ihb.ac.cn/english/mediumDetail.aspx?id=13 (accessed on 1 June 2013).

22. Markou, G.; Muylaert, K. Effect of light intensity on the degree of ammonia toxicity on PSII activity of Arthrospira platensis and Chlorella vulgaris. Bioresour. Technol. 2016, 216, 453-461. [CrossRef]

23. Lutzu, G.A.; Zhang, L.; Zhang, Z.; Liu, T.Z. Feasibility of attached cultivation for polysaccharidess production by Porphyridium cruentum. Bioprocess Biosyst. Eng. 2016, 40,1-11.

24. Dubois, M.; Gilles, K.A.; Hamilton, J.K.; Rebers, P.A.; Smith, F. Colorimetric method for determination of sugars and related substances. Anal. Chem. 1956, 28, 350-356. [CrossRef]

25. Bradford, M.M. A rapid and sensitive method for the quantitation of microgram quantities of protein utilizing the principle of protein-dye binding. Anal. Biochem. 1976, 72, 248-254. [CrossRef]

26. Ficner, R.; Lobeck, K.; Schmidt, G.; Huber, R. Isolation, crystallization, crystal structure analysis and refinement of B-phycoerythrin from the red alga Porphyridium sordidum at 2.2 A resolution. J. Mol. Biol. 1992, 228, 935-950. [CrossRef]

27. Bligh, E.G.; Dyer, W.J. A rapid method of total lipid extraction and purification. Can. J. Biochem. Physiol. 1959, 37, 911-917. [CrossRef] [PubMed]

28. Chen, L.; Liu, T.; Zhang, W.; Chen, X.L.; Wang, J.F. Biodiesel production from algae oil high in free fatty acids by two-step catalytic conversion. Bioresour. Technol. 2012, 111, 208-214. [CrossRef] [PubMed]

29. Golueke, C.G.; Oswald, W.J. The mass culture of Porphyridium cruentum. Appl. Microbiol. 1962, 10, $102-107$. [CrossRef]

30. Kim, H.M.; Oh, C.H.; Bae, H.J. Comparison of red microalgae (Porphyridium cruentum) culture conditions for bioethanol production. Bioresour. Technol. 2017, 233, 44-50. [CrossRef]

31. Xu, X.M.; Ye, H.C.; Li, G.F. Research advances in plant salt tolerance mechanism. Chin. J. Appl. Environ. Biol. 2000, 6, 379-387.

32. Ho, S.H.; Nakanishi, A.; Ye, X.T.; Chang, J.S.; Hara, K. Optimizing biodiesel production in marine Chlamydomona ssp. JSC4 through metabolic profiling and an innovative salinity-gradient strategy. Biotechnol. Biofuels 2015, 8, 48. [CrossRef]

33. Li, Y.; Huang, J.; Sandmann, G.; Chen, F. High-light and sodium chloride stress differentially regulate the biosynthesis of astaxanthin in Chlorella zofingiensis (Chlorophyceae). J. Phycol. 2009, 45, 635-641. [CrossRef]

34. Redfield, A.C. The biological control of chemical factors in the environment. Sci. Prog. 1960, 11, 150-170.

35. Razaghi, A.; Godhe, A.; Albers, E. Effects of nitrogen on growth and carbohydrate formation in Porphyridium cruentum. Cent. Eur. J. Biol. 2014, 9, 156-162.

36. Adda, M.; Merchuk, J.C.; Arad, S. Effect of nitrate on growth and production of cell-wall polysaccharides by the unicellular red alga Porphyridium. Biomass 1986, 10, 131-140. [CrossRef]

37. Pancha, I.; Chokshi, K.; Maurya, R.; Trivedi, K.; Kumar-Patidar, S. Salinity induced oxidative stress enhanced biofuel production potential of microalgae Scenedesmus sp. CCNM 1077. Bioresour. Technol. 2015, 189, 341-348. [CrossRef] [PubMed]

38. Jones, R.; Speer, H.; Kuyr, W. Studies on the growth of the red alga Porphyridium cruentum. Physiol. Plant. 1963, 16, 636-643. [CrossRef]

39. Singh, S.; Arad, S.; Richmond, A. Extracellular polysaccharides production in outdoor mass cultures of Porphyridium sp. in flat plate glass reactors. J. Appl. Phycol. 2000, 12, 269-275. [CrossRef]

40. Wang, J.; Chen, B.; Rao, X.; Huang, J.; Li, M. Optimization of culturing conditions of Porphyridium cruentum using uniform design. World J. Microbiol. Biotechnol. 2007, 23, 1345-1350. [CrossRef]

41. Cohen, Z.; Vonshak, A.; Richmond, A. Effect of environmental conditions on fatty acid composition of the red alga Porphyridium cruentum: Correlation to growth rate. J. Phycol. 1988, 24, 328-332.

(C) 2020 by the authors. Licensee MDPI, Basel, Switzerland. This article is an open access article distributed under the terms and conditions of the Creative Commons Attribution (CC BY) license (http://creativecommons.org/licenses/by/4.0/). 